\title{
The first record of Episoriculus umbrinus from Vietnam, with notes on the taxonomic composition of Episoriculus (Mammalia, Soricidae)
}

\author{
Alexei V. Abramov*, Anna A. Bannikova, Daria M. Chernetskaya, \\ Vladimir S. Lebedev, Viatcheslav V. Rozhnov
}

\begin{abstract}
The mitochondrial cytochrome $b$ and nuclear $A p o B$ and $R A G 2$ genes were used to estimate the phylogenetic relationships in Asiatic red-toothed shrews (Soricidae, Episoriculus). Based on molecular data, the genus Episoriculus seems to consist of at least seven valid species: E. baileyi, E. caudatus, E. leucops, E. macrurus, E. sacratus, E. soluensis, and E. umbrinus. Genetic distances among all of them are found to be of $8-16 \%$, with the only low distance (3.4\%) being that between E. baileyi and E. leucops. Taiwanese shrew E. fumidus shows high genetic divergence (16-17\% for $c y t b)$ from other species of Episoriculus. Based on both genetic and morphological data it should be attributed to a separate new genus Pseudosoriculus gen.n. Episoriculus umbrinus was found in Lao Cai Province, representing a new species record for the fauna of Vietnam; morphology-based diagnosis of this specimen has reliably been confirmed by molecular data.

How to cite this article: Abramov A.V., Bannikova A.A., Chernetskaya D.M., Lebedev V.S., Rozhnov V.V. 2017. The first record of Episoriculus umbrinus from Vietnam, with notes on the taxonomic composition of Episoriculus (Mammalia, Soricidae) // Russian J. Theriol. Vol.16. No.2. P.117-128. doi: 10.15298/ rusjtheriol.16.2.01
\end{abstract}

KEY WORDS: Episoriculus umbrinus, Vietnam, distribution, taxonomy, Pseudosoriculus gen.n.

Alexei V. Abramov [alexei.abramov.zin.ru], Zoological Institute, Russian Academy of Sciences, Saint Petersburg 199034, Russia, Joint Vietnamese-Russian Tropical Research and Technological Centre, Hanoi, Vietnam; Anna A. Bannikova [hylomys@mail.ru], Lomonosov Moscow State University, Moscow 119992, Russia; Daria M. Chernetskaya, Lomonosov Moscow State University, Moscow 119992, Russia; Vladimir S. Lebedev [wslebedev@mail.ru], Zoological Museum of Lomonosov Moscow State University, Moscow 125009, Russia; Viatcheslav V. Rozhnov [rozhnov.v@gmail.com], A.N. Severtsov Institute of Ecology and Evolution, Russian Academy of Sciences, Moscow 119071, Russia, Joint Vietnamese-Russian Tropical Research and Technological Centre, Hanoi, Vietnam.

\section{Первая находка Episoriculus umbrinus во Вьетнаме, с заметками по таксономическому составу Episoriculus (Mammalia, Soricidae)}

\section{А.В. Абрамов*, А.А. Банникова, Д.М. Чернецкая, В.С. Лебедев, В.В. Рожнов}

РЕЗЮМЕ. Митохондриальный (суtochrome $b$ ) и ядерные ( $A p o B$ и $R A G 2$ ) маркеры были использованы для оценки филогенетических связей в группе восточно-азиатских бурозубок(Soricidae, Episoriculus). По молекулярным данным, род Episoriculus включает не менее семи валидных видов: E. baileyi, E. caudatus, E. leucops, E. macrurus, E. sacratus, E. soluensis и E. umbrinus. Генетические дистанции между ними составляют 8-16\%, за исключением E. baileyi и E. leucops, дистанция между которыми всего 3.4\%. Тайваньская бурозубка E. fumidus значительно отличается от остальных видов Episoriculus (генетическая дивергенцию по cytb 16-17\%). На основании генетических и морфологических данных она выделена в отдельный новый род Pseudosoriculus gen.n. Episoriculus umbrinus был обнаружен в провинции Лао Кай и является новым видом для фауны Вьетнама; прежняя морфологическая идентификация этого экземпляра достоверно подтверждена молекулярными данными.

КЛЮЧЕВЫЕ СЛОВА: Episoriculus umbrinus, Вьетнам, распространение, таксономия, Pseudosoriculus gen.n. 


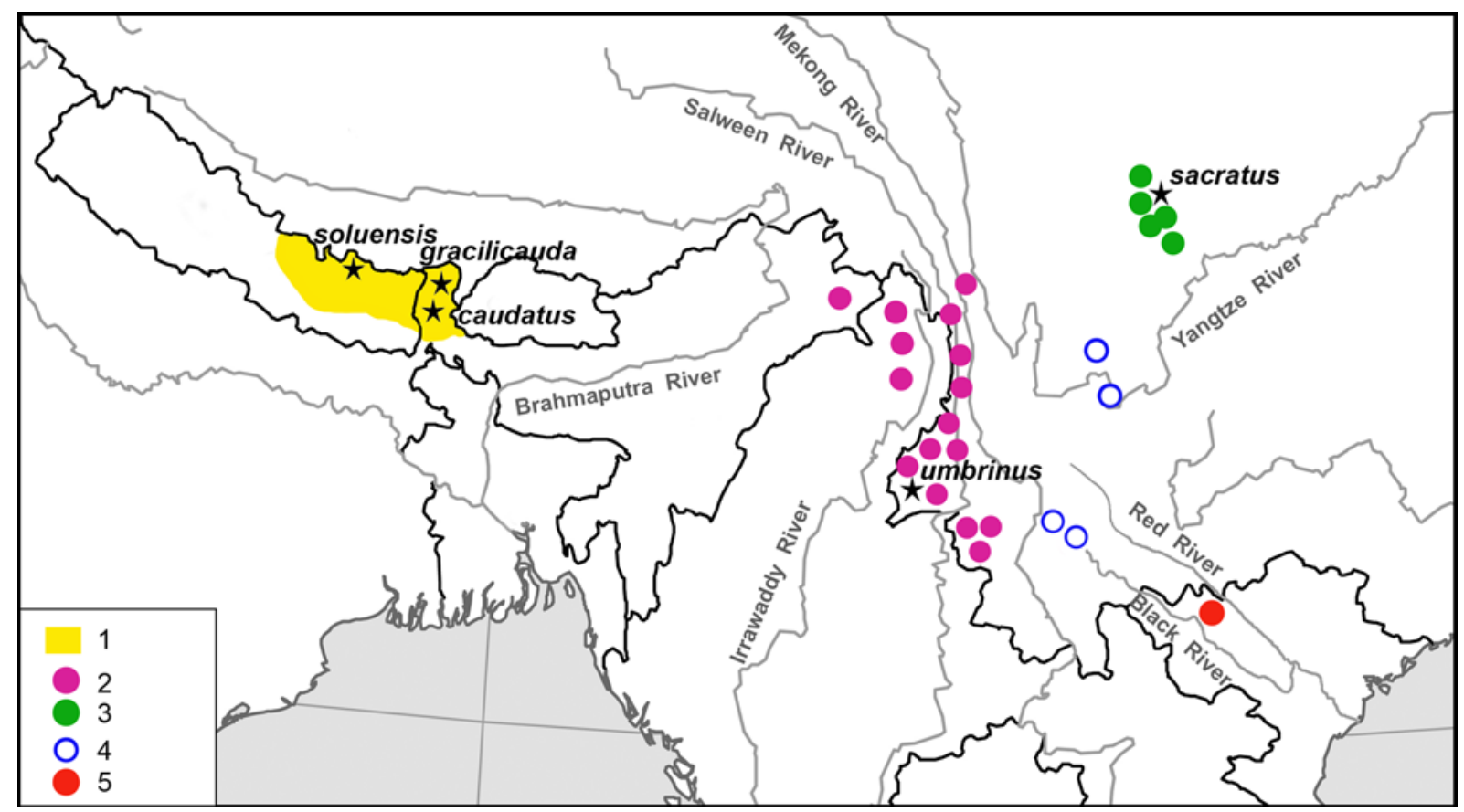

Figure 1. Distribution of Episoriculus caudatus s. lato: $1-$ E. caudatus and E. soluensis; $2-$ E. umbrinus; $3-$ E. sacratus; 4 - records of "E. caudatus" after Hoffmann \& Lunde (2008); 5 - specimen ZIN 96263, northern Vietnam. The type localities are indicated as asterisks.

\section{Introduction}

Asian red-toothed shrews of the Soriculus group are among of the poorly studied taxa of the tribe Nectogalini Anderson, 1879 (Lipotyphla, Soricidae). Shrews of this group are widely distributed in Asia - from northern China, southward to northern Vietnam and Myanmar, and from Kashmir to Taiwan (Hoffmann, 1986). Earlier, Soriculus Blyth, 1854 was treated in a broad sense and also included Episoriculus Ellerman et Morrison-Scott, 1966 and Chodsigoa Kastchenko, 1907 as the subgenera/synonyms (Hoffmann, 1986; Corbet \& Hill, 1992; Motokawa \& Lin, 2005). Only recently these taxa were given a full generic rank (Hutterer, 2005; Motokawa et al., 2008, 2009; He et al., 2010). The distinctions between these genera involve differences in the shape of articular facets of the mandible, the amount of brownish dental pigmentation, the number of upper unicuspid teeth, and the relative proportions of teeth, forefeet and tail (see Hoffmann, 1986). Phylogenetic relationships between genera of the Soriculus s. lato, as inferred by previous genetic studies, remain somewhat ambiguous, and the genus Episoriculus was found to be polyphyletic (Ohdachi et al., 2006; Dubey et al., 2007; He et al., 2010). Soriculus consists of one species, S. nigrescens (Gray, 1842), whereas the taxonomic content of Episoriculus and Chodsigoa vary in different checklists. According to Hutterer (2005), there are eight species in Chodsigoa and four in Episoriculus.

Based on the review by Hoffmann (1986), four species are recognized in Episoriculus: E. caudatus (Horsfield, 1851) distributed from Kashmir to northern
Myanmar and south-western China; E. leucops (Horsfield, 1855) distributed from central Nepal, Sikkim and Assam to southern China, northern Myanmar and northern Vietnam; E. macrurus (Blanford, 1888) distributed from central Nepal to western and southern China and to northern Myanmar and Vietnam; E. fumidus (Thomas, 1913) endemic to Taiwan. Episoriculus caudatus includes three subspecies (caudatus, sacratus and umbrinus) and E. leucops includes two subspecies (leucops and baileyi) (see Hoffmann, 1986; Hutterer, 2005).

Based on external and cranial characters, Motokawa \& Lin (2005) considered Episoriculus baileyi (Thomas, 1914) as a valid species. According to their data, E. baileyi is known from Sikkim and Assam in India, Myanmar and Vietnam, whereas E. leucops is restricted to Nepal. Further karyological studies revealed large differences in the karyotypes of E. caudatus s. lato (Motokawa et al., 2008, 2009). Shrews from Sichuan Province of China with $2 \mathrm{n}=58, \mathrm{FN}=108$ were treated as a distinct species E. sacratus (Thomas, 1911), the smaller form from Nepal with $2 \mathrm{n}=74, \mathrm{FN}=126$ - as $E$. soluensis Gruber, 1969 and the large form from Nepal with $2 \mathrm{n}=60, \mathrm{FN}=118$ - as E. caudatus. The fourth taxon, E. umbrinus (Allen, 1923), has not been karyotyped yet, but it differs from others in its skull measurements (Motokawa \& Lin, 2005; see also Motokawa et al., 2009). According to Motokawa et al. (2009), E. sacratus occurs in Sichuan Province of China; E. umbrinus is distributed in Assam, Myanmar, and Yunnan Province of China; E. soluensis occurs in Nepal and Sikkim, and E. caudatus is known from Nepal only (Fig. 1). 
According to all recent reviews (Hoffmann, 1986; Corbet \& Hill, 1992; Hutterer, 2005; Motokawa \& Lin, 2005; Motokawa et al., 2009), there are no shrews of the E. caudatus s. lato in Vietnam. However, in 2005, a specimen of red-toothed shrew, which undoubtedly belongs to this group, was collected from northern Vietnam (see Abramov et al., 2013).

Recent genetic studies (Ohdachi et al., 2006; Dubey et al., 2007; He et al., 2010) produced a multitude of $c y t b$ sequences of the Soriculus/Episoriculus in GenBank. However, it is not uncommon that sequences submitted to GenBank are assigned to species names without proper taxonomic verification. GenBank data is known to be error-ridden (Harris, 2003) and often lacks reference to the actual specimens examined (Ruedas et al., 2000), thus rendering molecular diagnostics unreliable. This disturbing trend was first noted 10 years ago and colloquially referred to as the "taxonomic impediment" (Carvalho et al., 2007). Quite often, the situation can be clarified only with the help of information on geographic origin of the specimen.

In this paper we try to use all the available data on distribution of the examined taxa of Episoriculus with the aim to evaluate the taxonomic position of the Vietnamese specimen, to elucidate the taxonomic affiliation of the sequences from GenBank, and to examine the phylogenetic relationships and taxonomic composition of the genus, focusing on the E. caudatus s. lato.

\section{Material and methods}

The specimen of Episoriculus cf. caudatus was collected in northern Vietnam, Lao Cai Province, near Tram Ton Station of Hoang Lien National Park, c. 6 km W of Sa Pa Town $\left(22^{\circ} 21^{\prime \prime N}, 103^{\circ} 46^{\prime \prime} \mathrm{E}\right)$ in December 2005. The collecting locality is shown in Fig. 1. This specimen (ZIN 96263) is deposited in the Zoological Institute of the Russian Academy of Sciences, Saint Petersburg, Russia. Other original material includes two specimens of Chodsigoa spp. and three specimens of genus Neomys Kaup, 1829.

A total of 65 sequences of $c y t b, 41$ sequences of $A p o B$ and 40 sequences of $R A G 2$, which are available from GenBank and attributed to several sources published earlier (Ohdachi et al., 2006; He et al., 2010; Abramov et al., 2017; Sheftel et al., 2017), was used in phylogenetic analyses (Appendix 1).

The complete mitochondrial cytb gene (1140 bp) and fragments of apolipoprotein $\mathrm{B}(A p o B)$ exon 26 and recombination-activating gene $2(R A G 2)$ exon 2 were amplified by PCR with the primer combination and conditions for amplification as in our previous studies (Bannikova et al., 2011; Abramov et al., 2017). The sequencing with each primer was performed by the ABI 3100-Avant autosequencing system using ABI PRISM ${ }^{\circledR B}$ BigDyeTM Terminator v.3.1. Cytb gene sequences were aligned by eye using BioEdit v.7.0.5.3 (Hall, 1999).
Phylogenetic reconstructions were performed with (1) the alignment of cytb sequences and (2) each of two nuclear genes separately. We did not combine nuclear and mitochondrial sequences in the same analyses because of the lack of nuclear data for most of Episoriculus lineages. We determined the best partitioning strategy for nuclear genes using the program Partition Finder (Lanfear et al., 2012). The cytb data set was partitioned into three codon positions. Phylogenetic trees were inferred in maximum likelihood (ML) with TreeFinder (October 2008 version) (Jobb, 2008) and maximum parsimony (MP) with PAUP v.4.0b (Swofford, 1998). To assess clade support, 1000 bootstrap pseudoreplicates were analyzed.

Genetic distances were calculated through MEGA5 (Tamura et al., 2011). To define natural groups based on mtDNA data we employed the Automatic Barcode Gap Discovery (ABGD) method (Puillandre et al., 2012). The automatic identification of the 'barcode gap' was performed using the ABGD application (available at http://www.abi.snv.jussieu.fr/public/abgd/ abgdweb.html) under the following parameters: Pmin (prior minimal distance) $=0.01$, Pmax (prior maximal distance $)=0.1, \mathrm{X}$ (relative gap width $)=1.0$. A matrix of uncorrected $p$-distances was taken as input.

\section{Results}

The final alignments have included $1140 \mathrm{bp}$ of the $c y t b, 518$ bp of $A p o B$ and 730 bp of RAG2. The optimum partitioning scheme for the nuclear genes identified by Partition Finder under the BIC criterion has corresponded to the scheme of three subsets per gene. The best-fit substitution models employed for each of the subsets are given in the Appendix 2.

The ML analysis of the cytb data has revealed six clades within Episoriculus with a genetic distance of 8$17 \%$ among them (Fig. 2, Table 1). These clades correspond to different species or groups of species: $E$. fumidus, E. macrurus, E. soluensis, E. caudatus, E. umbrinus, E. baileyi + E. leucops. Yet, the phylogenetic analysis of mitochondrial gene data by means of the ML and MP methods has failed to support the monophyly of the genus Episoriculus, because of the isolated position of the Taiwanese taxon E. fumidus outside the cluster of the rest of Episoriculus species. In the cytb tree it appears as sister to all Nectogalini, however with only moderate support in ML and without any support in MP. The genetic uncorrected $p$-distance between $E$. fumidus and other Episoriculus was found to be not less than $17 \%$. Besides E. fumidus, the most distant position on the mitochondrial tree is occupied by E. macrurus, which forms the basal branch in the cluster of Episoriculus s. stricto. The clade E. baileyi $+E$. leucops is found to be a sister taxon to the remaining Episoriculus species, with the genetic distance of not less than $12 \%$. Specimens from Yunnan (E. baileyi) and from Nepal (E. leucops) are rather close (3.4\%). The monophyly of the grouping E. caudatus/E. umbrinus is highly sup- 


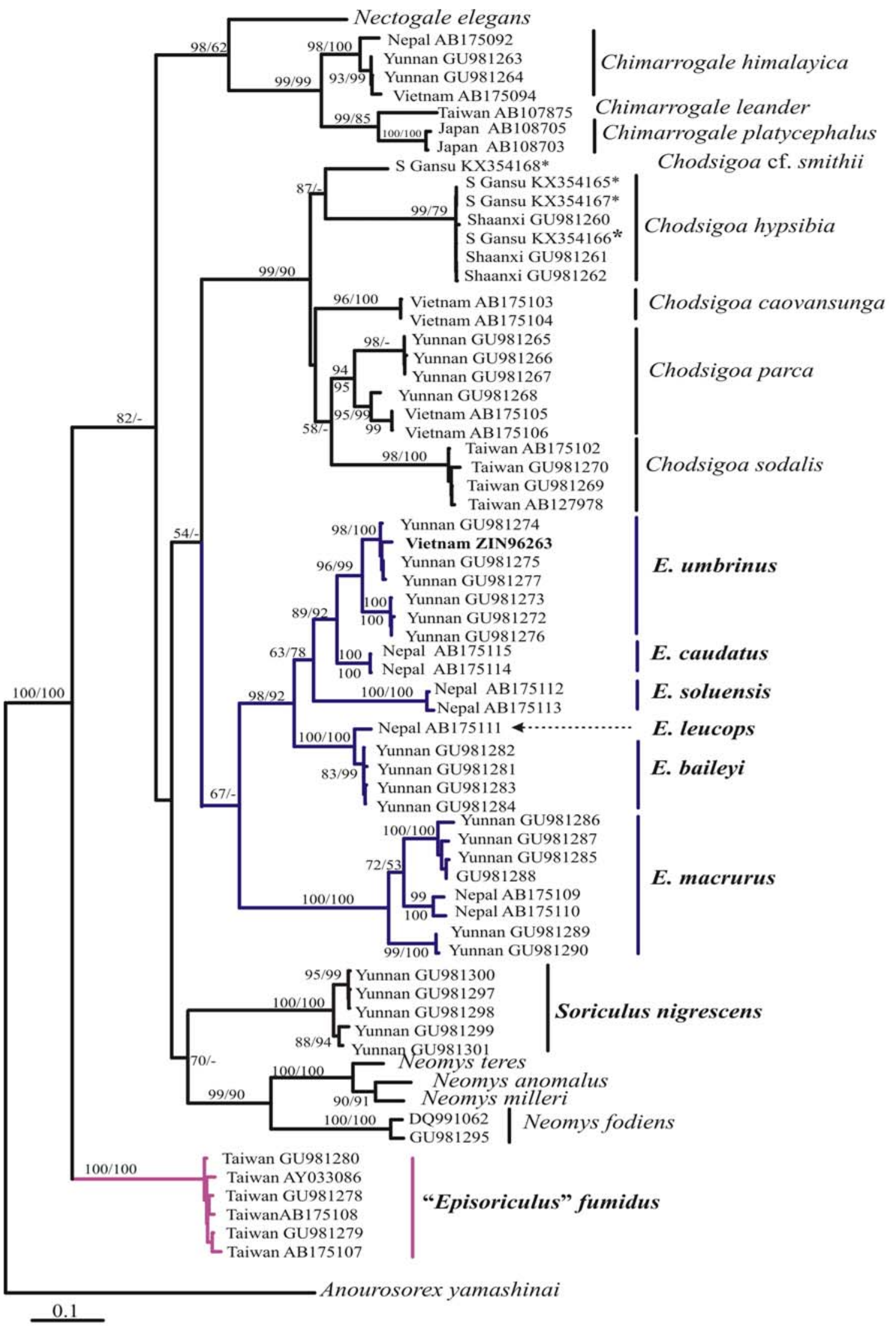

Figure 2. The ML phylogeny of Nectogalini as inferred from the complete cytb gene sequence. Sequences used from our previous studies (Abramov et al., 2017; Sheftel et al., 2017) are marked by asterisks. 
Table 1. The interspecific genetic p-distances within Episoriculus s. lato for $c y t b$.

\begin{tabular}{|l|c|c|c|c|c|c|}
\hline & "E". fumidus & E. macrurus & E. baileyi & E. leucops & E. umbrinus & E. caudatus \\
\hline "E". fumidus & & & & & & \\
\hline E. macrurus & $16.0 \pm 0.9$ & & & & & \\
\hline E. baileyi & $17.2 \pm 1.0$ & $15.1 \pm 0.9$ & & & & \\
\hline E. leucops & $17.6 \pm 0.0$ & $16.2 \pm 0.0$ & $3.4 \pm 0.0$ & & & \\
\hline E. umbrinus & $16.9 \pm 0.9$ & $15.5 \pm 0.8$ & $11.3 \pm 0.8$ & $12.3 \pm 0.8$ & & \\
\hline E. caudatus & $16.4 \pm 0.9$ & $15.0 \pm 0.8$ & $10.4 \pm 0.8$ & $11.4 \pm 0.9$ & $7.8 \pm 0.6$ & \\
\hline E. soluensis & $16.1 \pm 1.0$ & $16.1 \pm 0.9$ & $13.5 \pm 0.9$ & $13.1 \pm 0.9$ & $12.4 \pm 0.9$ & $11.8 \pm 0.8$ \\
\hline
\end{tabular}

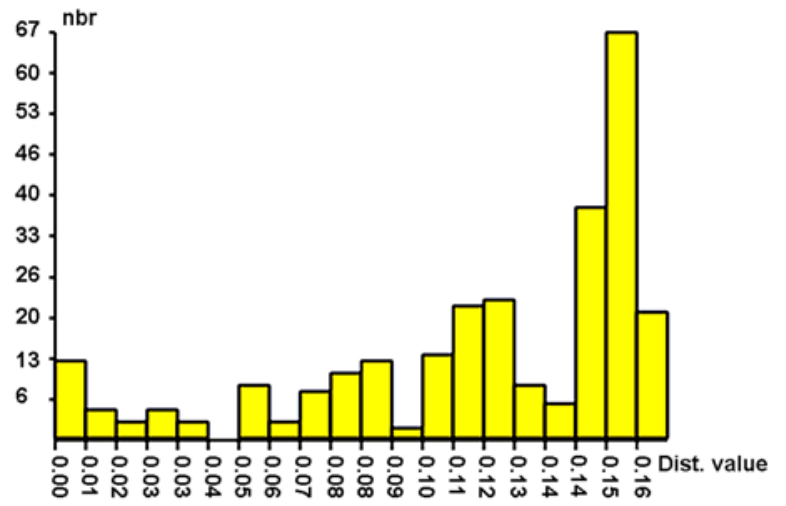

Figure 3. Distribution of the $p$-distances between haplotypes of $c y t b$ within Episoriculus.

ported. All the studied specimens of E. umbrinus from Yunnan form two lineages ( $p$-distance of $4 \%$ ). Our specimen ZIN 96263 from northern Vietnam falls into one of these groups and differs from Chinese specimens by $3.5 \%$, which is within the limits of intraspecies variability of E. umbrinus. Position of E. soluensis on the tree has a low support and thus remains unresolved with a tendency to join with $E$. caudatus/E. umbrinus group $(\sim 10 \%)$.

The distribution of genetic $p$-distances between haplotypes (Fig. 3) shows the most evident gap between 4 and $5 \%$. In the ABGD species delimitation method (Puillandre et al., 2012) with the exclusion of E. fumi$d u s$, eight groups have been found for primary partitions (prior maximal distance $p$ below 0.016): five of them correspond to E. leucops/baileyi, E. caudatus, E. umbrinus, E. soluensis and three groups are formed by splitting macrurus in three clusters. Thus, the result does not support baileyi as a distinct species that is separate from E. leucops.

The GenBank nuclear data of Episoriculus are very scarce, thus an efficient nuclear phylogenetic analysis is not possible yet. However, it is evident from our $A p o B$ and $R A G 2$ data that $E$. fumidus is very distant from other species of the genus (Figs 4A, B). It is placed as the sister branch to all Chodsigoa in the $A p o B$ gene tree with moderate support in ML and MP analyses. In the ML analysis of $R A G 2$ it is branching off after Neomys, but with the low bootstrap support. Within
Episoriculus s. stricto, E. macrurus is clearly separated from E. umbrinus and E. leucops/baileyi.

\section{Discussion}

Taxonomic position of the Vietnamese " $E$. caudatus"

The majority of researchers listed only two Episoriculus species, E. leucops (including baileyi) and $E$. macrurus, for Vietnam (Hoffmann, 1986; Corbet \& Hill, 1992; Hutterer, 2005; Hoffmann \& Lunde, 2008). However, many recent checklists of Vietnamese mammals also added E. caudatus to the species list (Dang et al., 1994, 2007, 2008; Kuznetsov, 2006). These "records" were based on the incorrect synonymy of "caudatus" and "baileyi" (see also Hoffmann, 1986), and in fact should be referred to E. baileyi (sensu Motokawa \& Lin, 2005). Hoffmann (1986: 468) stressed upon the fact that E. caudatus does not occur in Vietnam.

According to the initial description (Horsfield, 1855) and based on the examination of type specimen, $E$. baileyi is a large dark brown shrew with a tail only slightly longer than its body (see also Hoffmann, 1986). E. baileyi from Assam resembled this form in size and color, being just slightly smaller. Large red-toothed shrews from Northern Vietnam recorded in above-mentioned papers undoubtedly belong to E. leucops-baileyi group. Typical E. caudatus described from Darjeeling has smaller skull and body size, the shorter tail being equal to or less than head and body length.

Based on external and cranial characters, the specimen ZIN 96263 from Lao Cai Province was identified as E. caudatus s. lato (Abramov et al., 2013). New genetic data have confirmed this identification and placed it in E. umbrinus. All the studied specimens of E. umbrinus form two lineages ( $p$-distance for $c y t b$ $3.8 \pm 0.4 \%$ ) which probably represent distinct geographic populations. Allen (1923) described Soriculus caudatus umbrinus from Mucheng in western Yunnan (Fig. 1). Perhaps, the populations located eastward of Salween River (eastern and southern parts of Yunnan Province and northern Vietnam), may correspond to distinct taxa of the subspecies rank. An additional study of samples from Yunnan is required to clarify the taxonomic status of these lineages. 


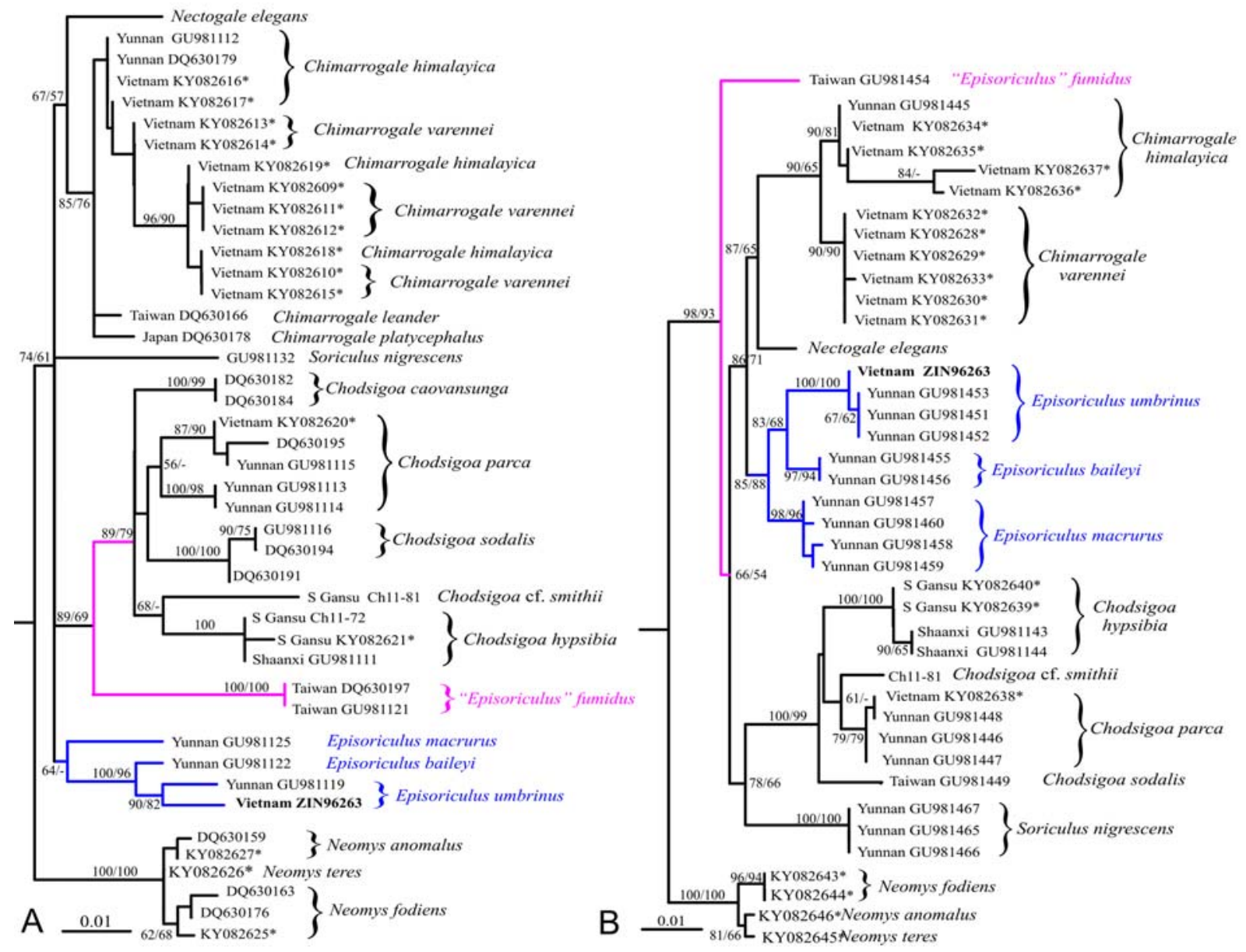

Figure 4. The ML trees of Nectogalini as inferred from the exons of $A p o B(\mathrm{~A})$ and $R A G 2(\mathrm{~B})$. Sequences used from our previous studies (Abramov et al., 2017; Sheftel et al., 2017) are marked by asterisks.

\section{Taxonomic content of Episoriculus}

All the taxa belonging to Episoriculus s. stricto (i.e., E. baileyi, E. caudatus, E. leucops, E. macrurus, E. soluensis, and E. umbrinus) form highly or moderately supported clades in the ML and MP analyses with genetic distances $(c y t b)$ among them of approximately $8-16 \%$. These data have confirmed the previous morphological and karyological data (Motokawa \& Lin, 2005; Motokawa et al., 2008, 2009) and testified the species rank of most studied taxa. However, the distance between $E$. baileyi and E. leucops was low, just $3.4 \%$, that contradicts the morphological findings by Motokawa \& Lin (2005). According to the current genetic species concept (Baker \& Bradley, 2006) the value of more than $5 \%$ of divergence in the $c y t b$ gene is indicative of species rather than subspecies rank and values of $<5 \%$ have a high probability of being indicative of conspecific populations, however merit additional study concerning specific status. Thus, an additional study is needed to evaluate the taxonomic rank of these two forms.

For one of species from this group, E. sacratus from Sichuan, genetic data are still absent. However, mor- phological and karyological data confirm that it belongs to Episoriculus s. stricto (Motokawa \& Lin, 2005; Motokawa et al., 2008, 2009).

Taxonomic position of "Episoriculus" fumidus

Episoriculus fumidus was described from central Taiwan (Thomas, 1913) and is currently classified as a member of the genus Episoriculus based on its morphological characters, including the dental formula (Hoffmann, 1986; Corbet \& Hill, 1992; Hutterer, 2005; Lin \& Motokawa, 2010).

Molecular data have supported the position of the Taiwanese E. fumidus as a monotypic clade within the tribe Nectogalini. This separate branch lies outside of Episoriculus, with the large genetic distance $(\sim 17 \%$, $c y t b)$ between $E$. fumidus and the other clades of Soriculus s. lato (Fig. 2) as demonstrated by the analyses of both the mitochondrial $c y t b$ gene and two nuclear loci. Other molecular phylogenetic studies have repeatedly showed the paraphyletic status of Episoriculus when $E$. fumidus is included (Ohdachi et al., 2006; Dubey et al., 2007; He et al., 2010). In our work, as in the early 
studies (He et al., 2010), gene trees obtained from individual loci (including BRCA1 which is absent in the present study) show different topologies. However, this does not imply that the conflict among genes is significant because the levels of support for each rival topology are just moderate or low. The uncertainty of the position of E. fumidus makes it difficult to provide a clear interpretation of its relationships with other Nectogalini. Taking into consideration all the genetic data available for the tribe by now, it is possible to conclude only that $E$. fumidus belongs to a subclade that includes all genera except Neomys, and that the Taiwanese redtoothed shrew indisputably represents a lineage separate from the genus Episoriculus. As inferred in $\mathrm{He}$ et al. (2010), the time of divergence between E. fumidus and its sister taxa ( 5.04 Mya, Early Pliocene) is comparable to or even higher than those among such distinct genera as Chimarrogale, Episoriculus s. stricto, Chodsigoa and Nectogale.

Despite the similar dental formula, E. fumidus is clearly distinct from other Episoriculus taxa by the external and cranial characters (Jameson \& Jones, 1977; Hoffmann, 1986; see below). Considering that E. fumidus demonstrates a unique combination of external, craniodental and genetic characteristics and belongs to a distinct phylogenetic lineage, it should not be included in the genus Episoriculus s. stricto. Retention of $E$. fumidus in Episoriculus, most probably, renders the latter paraphyletic, which violates the major principle of phylogenetic taxonomy. In our opinion, the Taiwanese red-toothed shrew should be assigned to a new genus Pseudosoriculus gen.n., of which the description follows.

\section{Systematic part}

Family: Soricidae Fischer, 1817

Subfamily: Soricinae Fischer, 1817

Pseudosoriculus Abramov, Bannikova, Chernetskaya, Lebedev et Rozhnov, gen.n.

Type species: Soriculus fumidus Thomas, 1913

Distribution: Endemic of Taiwan. Widespread in the mountains of main island of Taiwan, between 1,000 and 3,600 $\mathrm{m}$ above sea level (Lin \& Motokawa, 2010).

Contents: The type species only.

Etymology: The name of the new genus is derived from the Greek word "pseudes" (false) and the generic name Soriculus previously attributed to this taxon. Gender is masculine.

Diagnosis: A medium-sized shrew. Fur covering head and body blackish brown, under surface slightly lighter than upper. Tail shorter than head and body, dark brown, little lighter below. The skull with short, narrow rostrum. Angular process quite long and curved; coronoid process high, with converging sides. Upper tooth-row with four antemolars (A1-A4); fourth antemolar very small, and tightly wedged between $\mathrm{A} 3$ and
P4. Posterior margin of fourth premolar, first and second molars not strongly concave. The lower incisor relatively long. The dental formula is 1.4.1.3/1.1.1.3, total 30 . Teeth are red-tipped. The karyotype has $2 \mathrm{n}=64$, $\mathrm{FN}=116$ (Motokawa et al., 1998).

Comparisons: Teeth of Pseudosoriculus gen.n. are red-tipped in contrast to white-toothed Nectogale and Chimarrogale. New genus has four antemolars in upper tooth-row instead of three antemolars in Chodsigoa. It differs from Soriculus in small body size and relatively long tail (at average $75 \%$ of head and body length in contrast to $50 \%$ in latter). It is clearly distinct from Episoriculus by the relatively short tail, the narrow and shortened rostral part of the skull and the mandible with long angular and coronoid processes.

New genus represents a distinct phylogenetic lineage of Nectogalini, with the large genetic distance $(\sim 17 \%, c y t b)$ between it and the other clades of Soriculus s. lato.

ACKNOWLEDGEMENTS. Field works in Vietnam were possible due to support of the Joint Vietnamese-Russian Tropical Research and Technological Centre (Hanoi, Vietnam). We thank the administration of Hoang Lien National Park for aid in the management of our study. We also thank A.V. Shchinov for his great help during fieldwork. Dr. Dmitri Logunov (Manchester Museum, UK) is thanked for improving the English of the first draft. We are very grateful to six anonymous reviewers for their helpful and constructive comments on the early version of the manuscript. The study was supported in part by the Russian Foundation for Basic Research (grants 16-04-00085, 17-04-00065, and 1529-02771 ofi-m) and the Zoological Institute' Program AAAA-A17-117022810195-3.

\section{References}

Abramov A.V., Bannikova A.A., Lebedev V.S. \& Rozhnov V.V. 2017. Revision of Chimarrogale (Lipotyphla: Soricidae) from Vietnam with comments on taxonomy and biogeography of Asiatic water shrews // Zootaxa. Vol.4232. No.2. P.216-230.

Abramov A.V., Can D.N., Hai B.T. \& Son N.T. 2013. An annotated checklist of the insectivores (Mammalia, Lipotyphla) of Vietnam // Russian Journal of Theriology. Vol.12. No.2. P.57-70.

Allen G.M. 1923. New Chinese insectivores // American Museum Novitates. No.100. P.1-11.

Bannikova A.A., Abramov A.V., Borisenko A.V., Lebedev V.S. \& Rozhnov V.V. 2011. Mitochondrial diversity of the white-toothed shrews (Mammalia, Eulipotyphla, Crocidura) in Vietnam // Zootaxa. No.2812. P.1-20.

Baker R.J. \& Bradley R.D. 2006. Speciation in mammals and the genetic species concept // Journal of Mammalogy. Vol.87. No.4. P.643-662.

Carvalho M.R., Bockmann F.A., Amorim D.S., Brand C.R.F., Vivo M., Figueiredo J.L., Britski H.A., Pinna M.C.C., Menezes N.A., Marques F.P.L., Papavero N., Cancello E.M., Crisci J.V., McEachran J.D., Schelly R.C., Lund- 
berg J.G., Gill A.C., Britz R., Wheeler Q.D., Stiassny M.L.J., Parenti L.R., Page L.M., Wheeler W.C., Faivovich J., Vari R.P., Grande L., Humphries C.J., DeSalle R., Ebach M.C. \& Nelson G.J. 2007. Taxonomic impediment or impediment to taxonomy? A commentary on systematics and the Cybertaxonomic-Automation Paradigm // Evolutionary Biology. Vol.34. P.140-143.

Castiglia R., Annesi F., Aloise G. \& Amori G. 2007. Mitochondrial DNA reveals different phylogeographic structures in the water shrews Neomys anomalus and N. fodiens (Insectivora: Soricidae) in Europe // Journal of Zoological Systematics and Evolutionary Research. Vol.45. No.3. P.255-262.

Corbet G.B. \& Hill J.E. 1992. The Mammals of the Indomalayan Region: A Systematic Review. Oxford: Oxford University Press. 488 p.

Dang H.H., Dao V.T., Cao V.S., Pham T.A. \& Hoang M.K. 1994. [Checklist of Mammals in Vietnam]. Hanoi: Publishing House "Science and Technics". 168 p. [in Vietnamese].

Dang H.H., Hoang M.K., Le X.C., Nguyen X.D., Vu D.T. \& Dang H.P. 2007. [Mammals of Vietnam. Morphology, Biology and Ecology of Some Species]. Vol.1. Hanoi: Science and Technics Publishing House. 232 p. [in Vietnamese].

Dang N.C., Endo H., Nguyen T.S., Oshida T., Le X.C., Dang H.P., Lunde D.P., Kawada S.-I., Hayashida A. \& Sasaki M. 2008. [Checklist of Wild Mammal Species of Vietnam]. Hanoi: Primate Research Institute, Inuyama, Japan \& Institute of Ecology and Biological Resources. 400. p. [in Vietnamese].

Dubey S., Salamin N., Ohdachi S.D., Barriere P. \& Vogel P. 2007. Molecular phylogenetics of shrews (Mammalia: Soricidae) revel timing of transcontinental colonizations // Molecular Phylogenetics and Evolution. Vol.44. P.126137.

Hall T.A. 1999. BioEdit: A user-friendly biological sequence alignment editor and analysis program for Windows 95/ 98/NT // Nucleic Acids Symposium Series. Vol.41. P.9598.

Harris D.J. 2003. Can you bank on GenBank? // Trends in Ecology \& Evolution. Vol.18. P.317-319.

He K., Li Y.J., Brandley M.C., Lin L.-K., Wang Y.X., Zhang Y.P. \& Jiang X.L. 2010. A multi-locus phylogeny of Nectogalini shrews and influences of the paleoclimate on speciation and evolution // Molecular Phylogenetics and Evolution. Vol.56. No.2. P.734-746.

Hoffmann R.S. 1986. A review of the genus Soriculus (Mammalia: Insectivora) // Journal of the Bombay Natural History Society. Vol.82. No.3. P.459-481.

Hoffmann R.S. \& Lunde D. 2008. Order Erinaceomorpha, Order Soricomorpha // Smith A.T. \& Xie Y. (eds.). A Guide to the Mammals of China. Princeton: Princeton University Press. P.292-327.

Horsfield T. 1855. Brief notices of several new or littleknown species of Mammalia, lately discovered and collected in Nepal, by Brian Houghton Hodgson, Esq. // Annals and Magazine of Natural History. Ser.2. No.16. P.101-114.

Hutterer R. 2005. Order Erinaceomorpha, Order Soricomorpha // Wilson D.E. \& Reeder D.M. (eds.). Mammal Species of the World. A Taxonomic and Geographic Reference. Third edition. Baltimore: Johns Hopkins Press. P. 212-311.
Jameson E.W. \& Jones G.S. 1977. The Soricidae of Taiwan // Proceedings of the Biological Society of Washington. Vol.90. P.459-482.

Jobb G. 2008. TREEFINDER, version of October 2008. Munich, Germany. Distributed by the author. Available from: http:// www.treefinder.de (accessed 17 January 2017).

Kuznetsov G.V. 2006. [Mammals of Vietnam]. Moscow: KMK Scientific Press. 428 p. [in Russian].

Lanfear R., Calcott B., Ho S.Y.W. \& Guindon S. 2012. PartitionFinder: combined selection of partitioning schemes and substitution models for phylogenetic analyses // Molecular Biology and Evolution. Vol.29. P.16951701.

Lin L.-K. \& Motokawa M. 2010. Mammals of Taiwan. Vol.1. Soricomorpha. 89 p. http://mammal.biota.biodiv.tw/

Motokawa M. \& Lin L.-K. 2005. Taxonomic status of Soriculus baileyi (Insectivora, Soricidae) // Mammal Study. Vol.30. P.117-124.

Motokawa M., Harada M., Lin L.-K, Cheng H.C. \& Koyasu K. 1998. Karyological differentiation between two Soriculus (Insectivora: Soricidae) from Taiwan // Mammalia. Vol.62. P.541-547.

Motokawa M., Harada M., Mekada K. \& Shrestha K.C. 2008. Karyotypes of three shrew species (Soriculus nigrescens, Episoriculus caudatus and Episoriculus sacratus) from Nepal // Integrative Zoology. Vol.3. P.180185.

Motokawa M., Wu Y. \& Harada M. 2009. Karyotypes of six soricomorph species from Emei Shan, Sichuan Province, China // Zoological Science. Vol.26. P.791-797.

Ohdachi S.D., Hasegawa M., Iwasa M.A., Vogel P., Oshida T., Lin L.-K. \& Abe H. 2006. Molecular phylogenetics of soricid shrews (Mammalia) based on mitochondrial cytochrome $b$ gene sequences: with special reference to the Soricinae // Journal of Zoology. Vol.270. P.177-191.

Puillandre N., Lambert A., Brouillet S. \& Achaz G. 2012. ABGD, automatic barcode gap discovery for primary species delimitation // Molecular Ecology. Vol.21. P.1864-1877.

Ruedas L.A., Salazar-Bravo J., Dragoo J.W. \& Yates T.L. 2000. The importance of being earnest: what if anything constitutes a «specimen examined?»// Molecular Phylogenetics and Evolution. Vol.17. P.129-32.

Sheftel B.I., Bannikova A.A., Fang Y., Demidova T.B., Alexandrov D.Yu., Lebedev V.S. \& Sun Y.-H. 2017. [Notes on the fauna, systematics and ecology of small mammals in Southern Gansu, China] // Zoologicheskii Zhurnal. Vol.96. No.2. P.232-248 [in Russian with English summary].

Swofford D.L. 1998. PAUP*. Phylogenetic Analysis Using Parsimony (*and Other Methods). Version 4. Sunderland, MA: Sinauer Associates.

Tamura K., Peterson D., Peterson N., Stecher G., Nei M. \& Kumar S. 2011. MEGA5: molecular evolutionary genetics analysis using maximum likelihood, evolutionary distance, and maximum parsimony methods // Molecular Biology and Evolution. Vol.28. P.2731-2739.

Thomas O. 1913. Four new shrews // Annals and Magazine of Natural History. Ser.8. No.11. P.214-218. 
๕

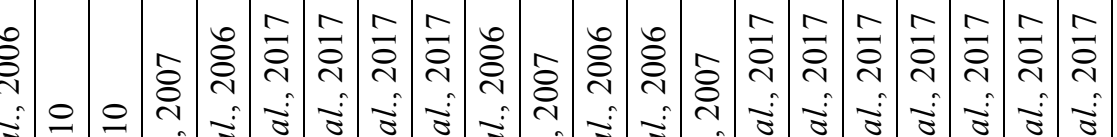

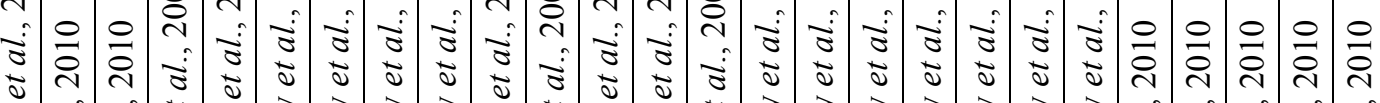

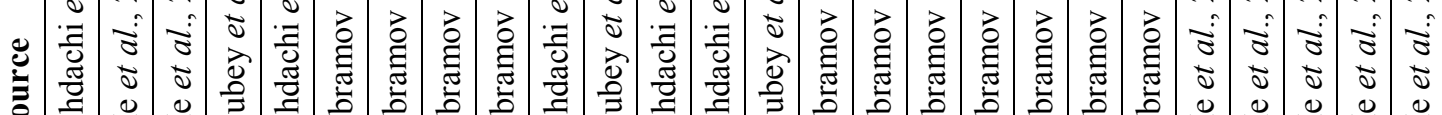

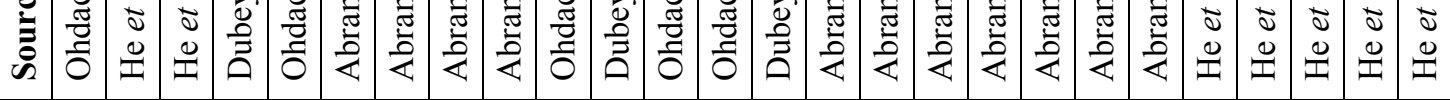

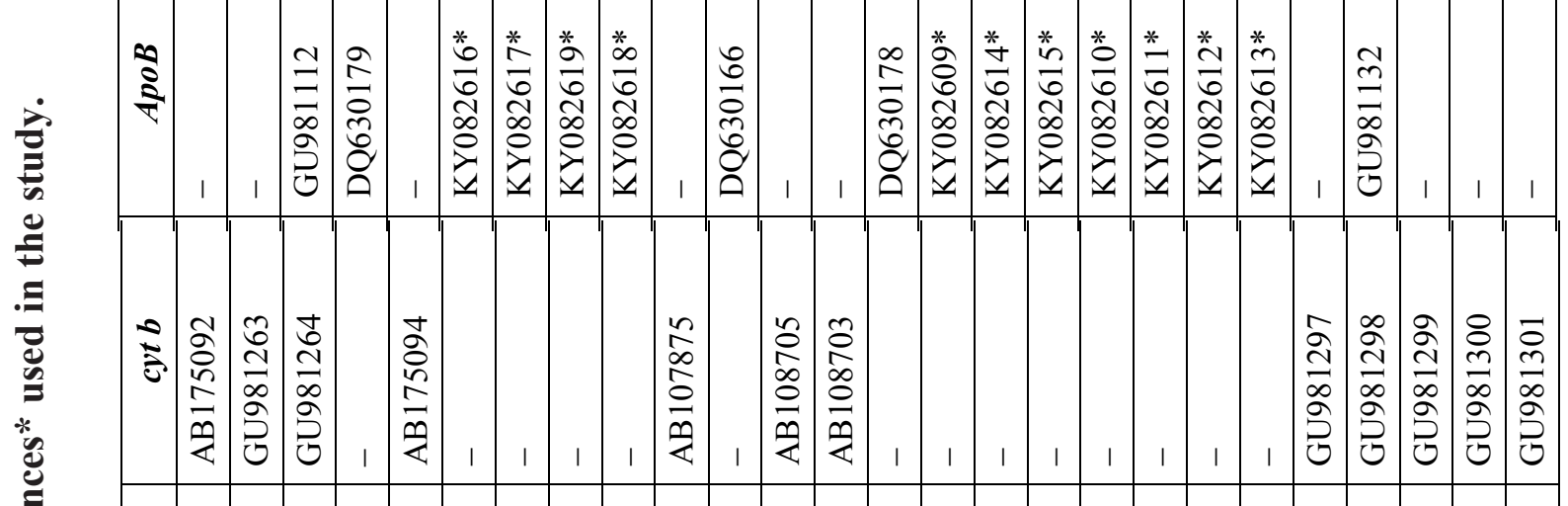

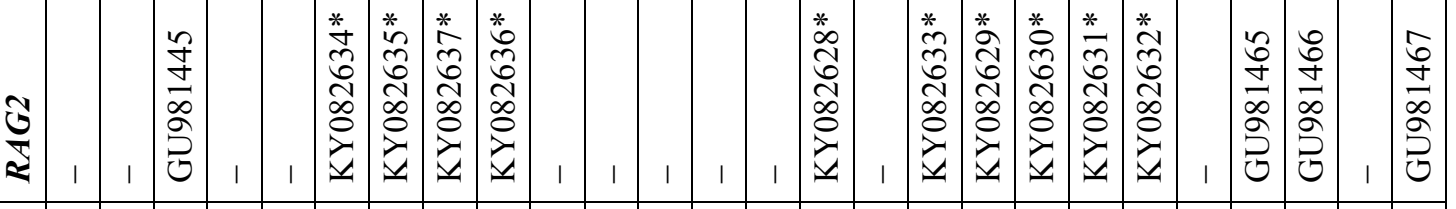

莺

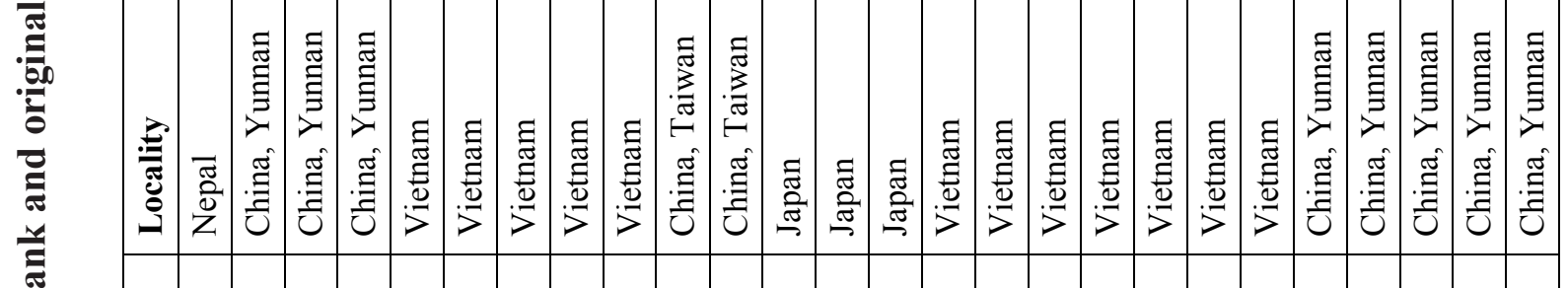

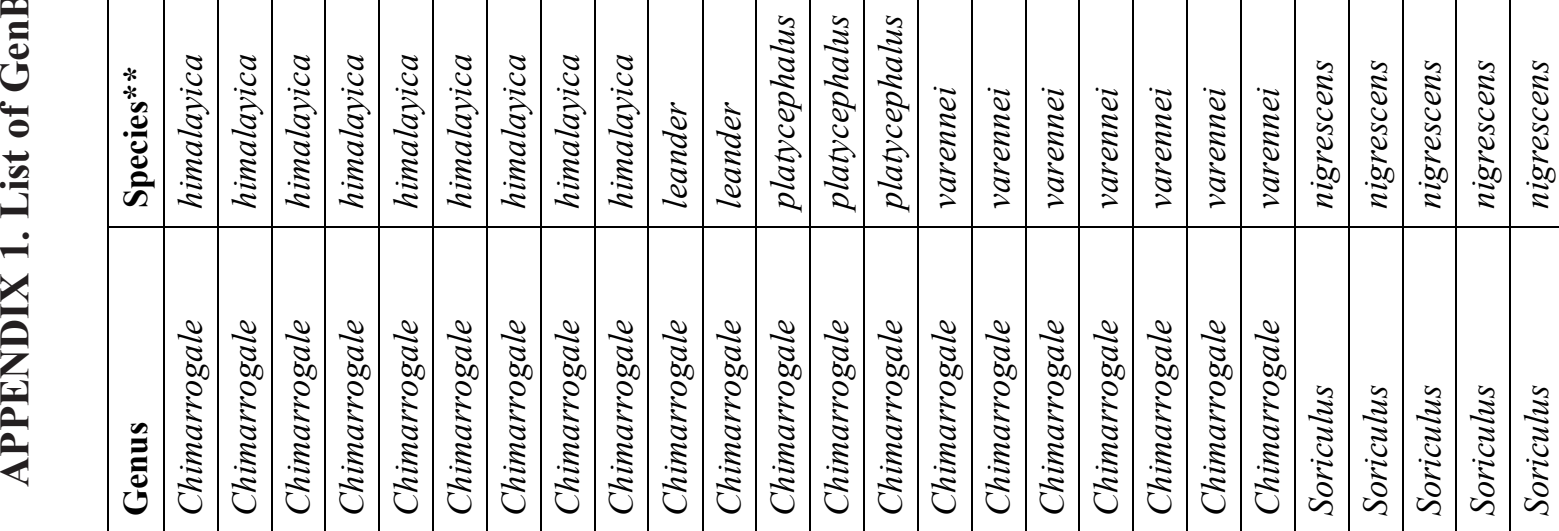




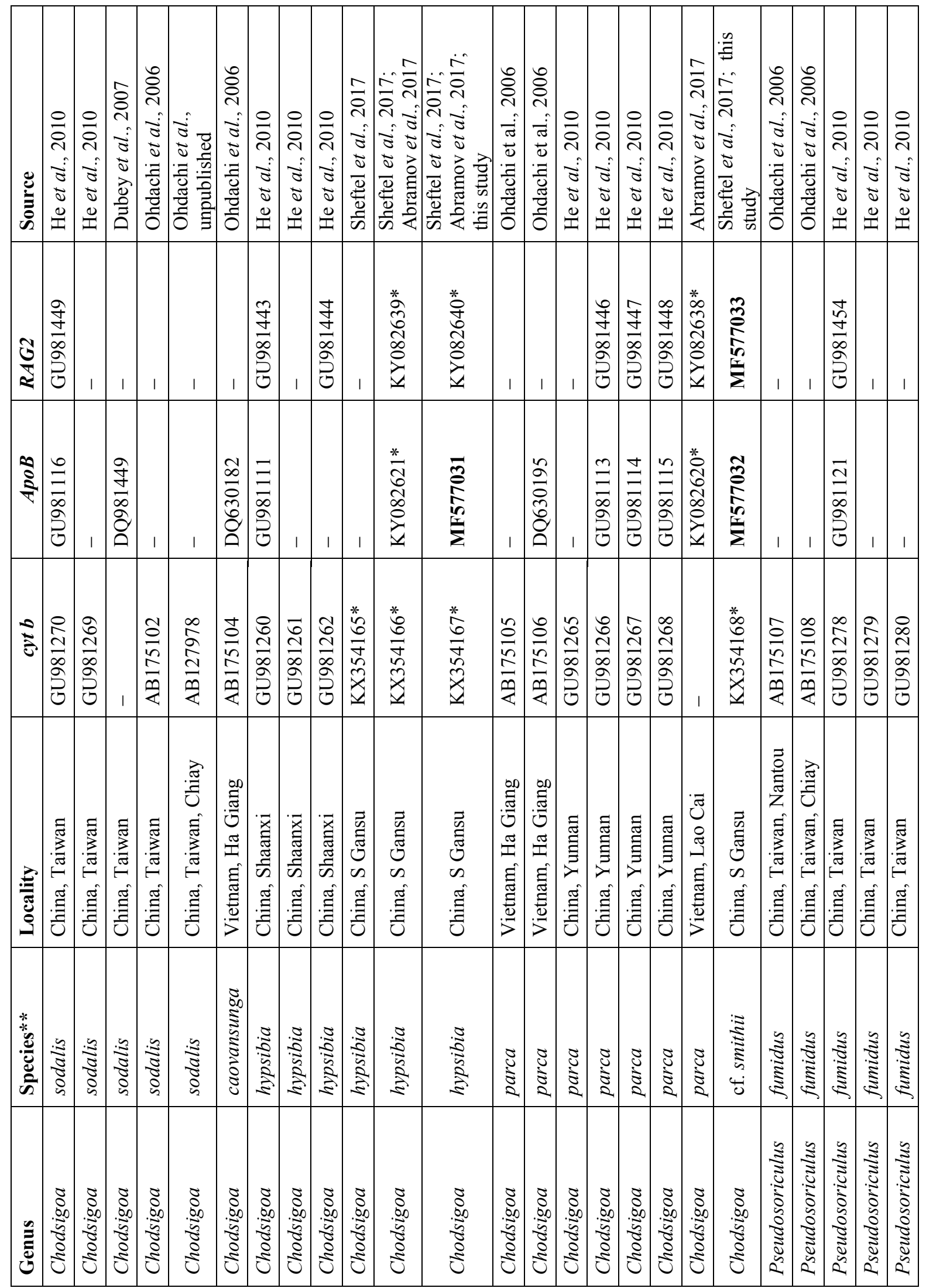




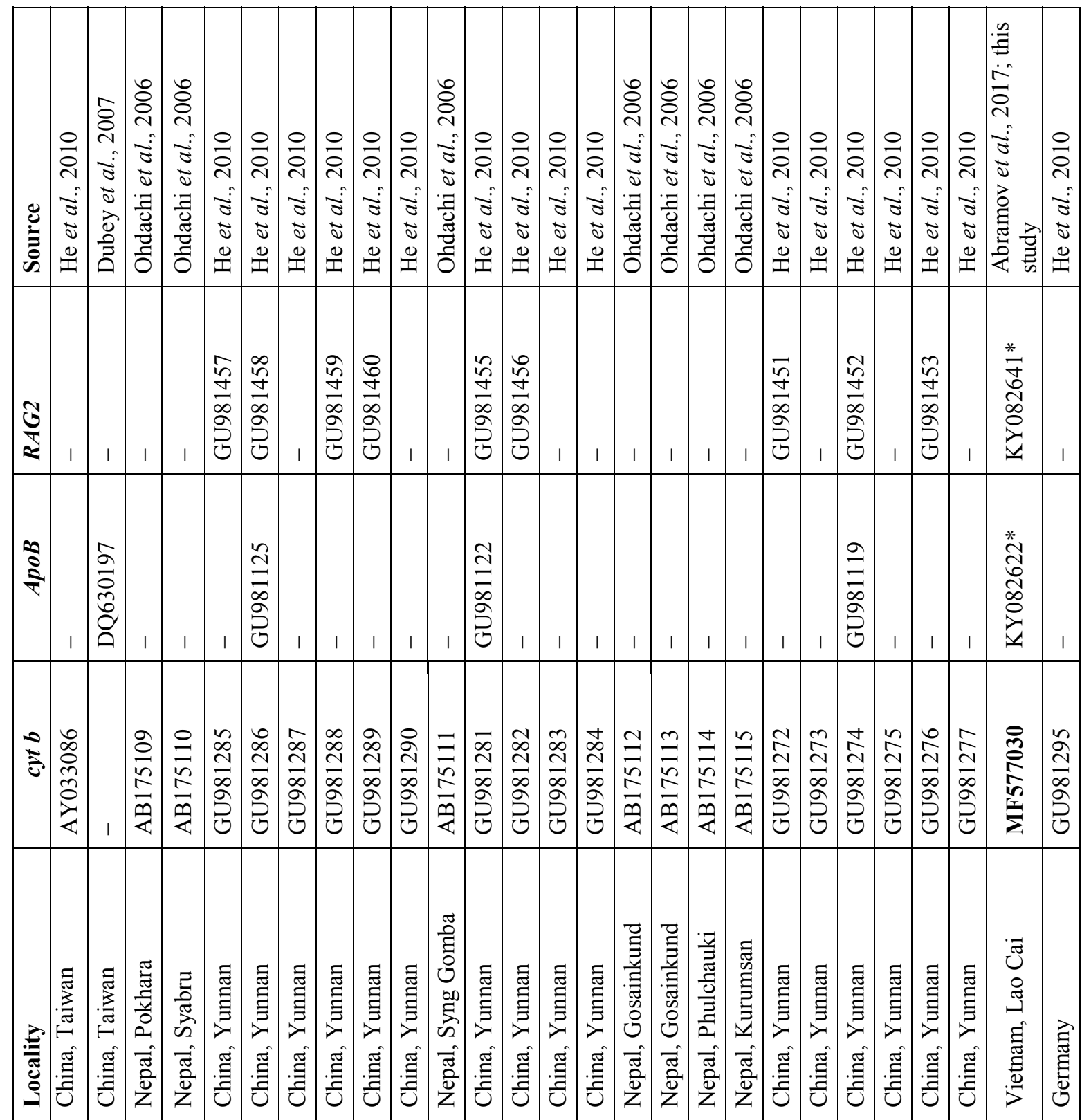

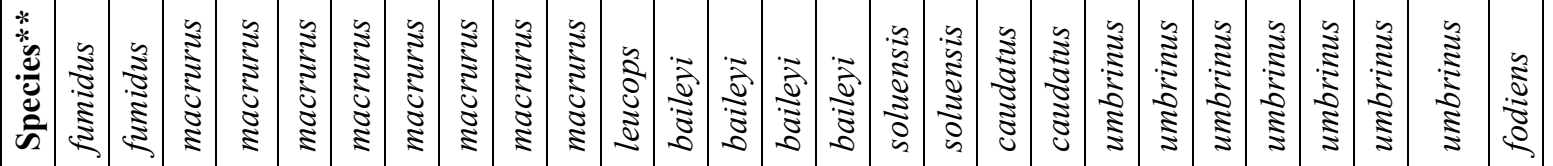

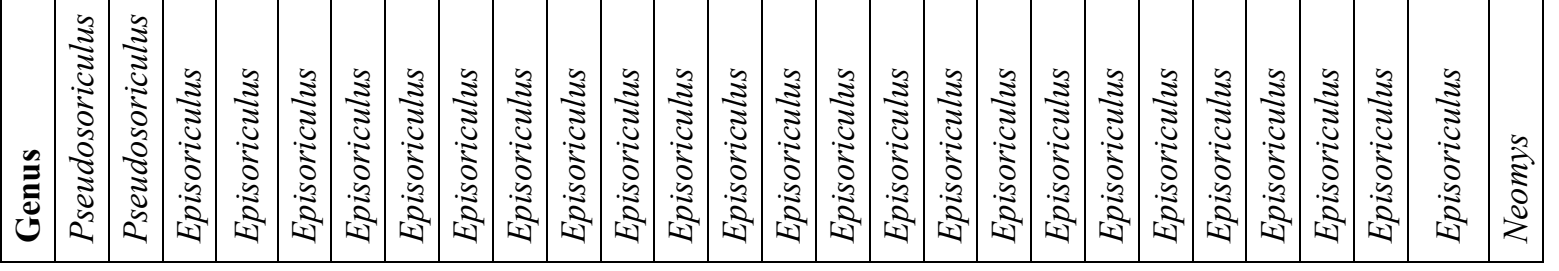



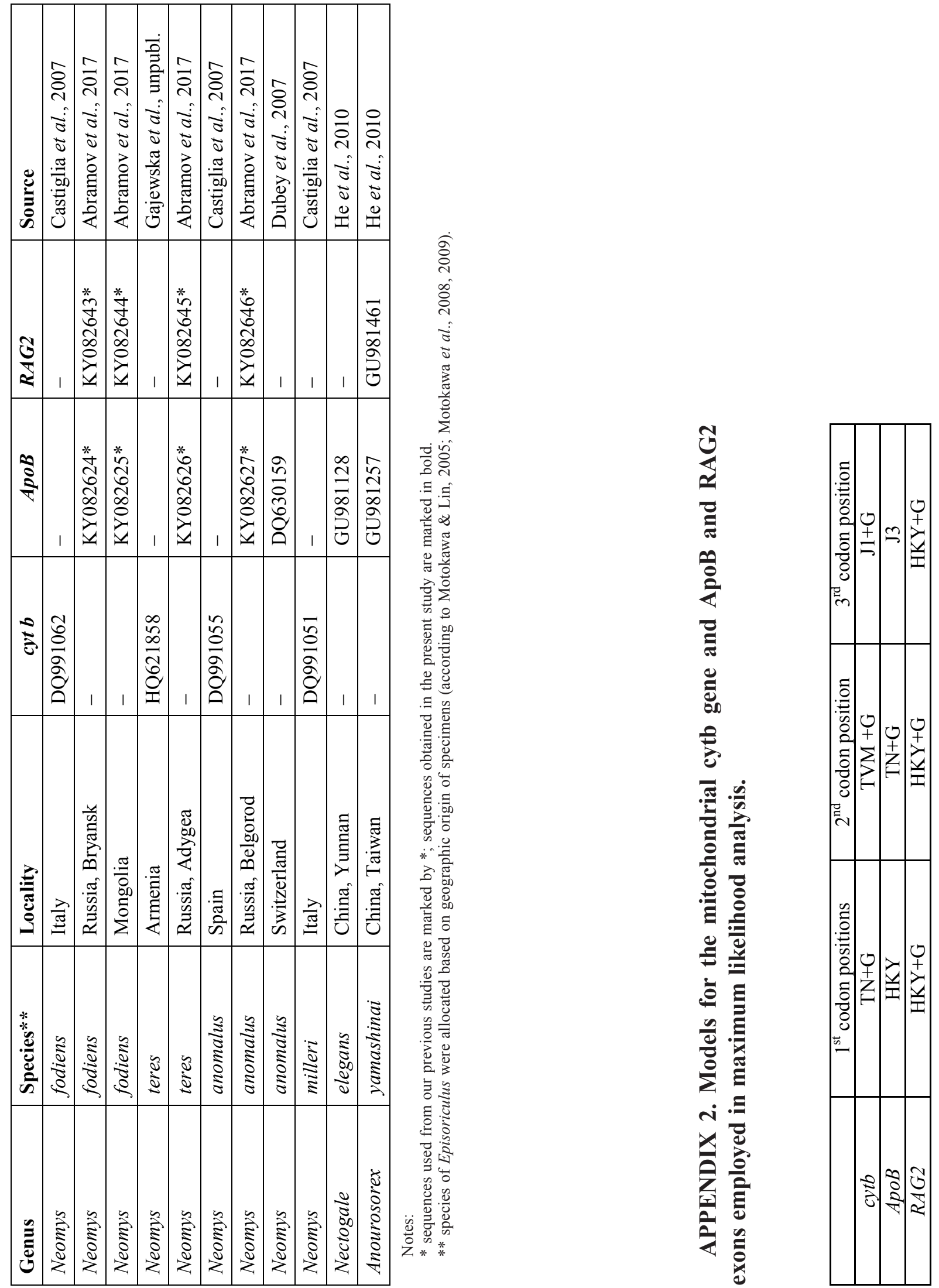